DOI: $\underline{\text { https://doi.org/10.24867/07DS01Baic }}$

\title{
UTVRĐIVANJE KARAKTERISTIKA PARKIRANJA U ZONI TRGA REPUBLIKE U NOVOM SADU
}

\section{ANALYSIS OF PARKING CHARACTERISTICS IN THE AREA OF TRG REPUBLIKE IN NOVI SAD}

\begin{abstract}
Oblast-SAOBRAĆAJ
Kratak sadržaj - U ovom radu vršeno je istraživanje o karakteristikama parkiranja u zoniTrga Republike. Zadatak je bio da se analiziraju dobiveni podaci $i$ da se uoče prednosti $i$ nedostaci parkirališta. Cilj ovog istraživanja je bio da se prikupe podaci o broju korisnika parkirališta na osnovu kojh će se utvrditi karakteristike parkirališta.
\end{abstract}

Abstract - In this paper research was conducted to obitain information about the characteristics of parking in the area of Trg Republike. The goal vaw to analize the obtained results in order to recognize the pros and cons of te number of users of the parking lot according to which the characteristics of the parking lot will be detarmined.

Ključne reči: Drumski i gradski terminali,parkirališta, Trg Republike

Keywords: Road and City terminals, parking lots, Trg Republike

\section{UVOD}

Konstantan porast broja stanovnika i stepena motorizacije odlika je svih većih gradova kako u Evropi tako i u svetu. Parkiranje vozila u centralnim parkirnim zonama je masovna pojava. U svim gradovima jedan od glavnih problema jeste manjak parking mesta u centralnim delovima grada. Potreba za povećanjem parking mesta iz godine u godinu je sve veća, a naročito u centralnim delovima grada. U centralnim delovima gradova je povećana potražnja za parkig mestima, jer je najveća koncentracija aktivnosti koje privlače i veliki broj korisnika parkinga. Predmet ovog rada jeste analiza karakteristika parkiranja u zoni Trga Republike u Novom Sadu. Cilj ovog istraživanja jeste da se prikupe podaci o broju korisnika parkirališta na osnovu kojih će se utvrditi karakteristike parkiranja, kao i o broju korisnika koji parkiranje plaćaju.

\section{SISTEM PARKIRANJA U NOVOM SADU}

Problem parkiranja u Novom Sadu kao i rešavanjem ovog problema na što kvalitetniji način bavi se Javno komunalno preduzeće "Parking servis", osnovano 16.

\section{NAPOMENA:}

Ovaj rad proistekao je iz master rada čiji mentor je bio dr Zoran Papić, vanr. prof. decembra 2004. godine od strane Skupštine grada Odluka o osnivanju preduzeća bila je motivisana upravo potrebom unapređenja odnosa $\mathrm{u}$ oblasti parkiranja vozila kako bi se stvorili uslovi za povećanje pristupačnosti, te iskoristile javne gradske površine sa svrhom postepenog proširenja parkirališnih kapaciteta.

Delatnost preduzeća je održavanje, uređenje parkinga i javnih garaža, uklanjanje nepropisno parkiranih vozila koja ometaju sve vidove saobraćaja, uklanjanje vozila zatečenih na javnim zelenim površinama i druge poslove koji se odnose na rad parkirališta i javnih garaža.

Zonski sistem parkiranja predstavlja najnoviji sistem parkiranja koji je nastao kao rešenje problema parkiranja sa kojim se korisnici parking prostora svakodnevno susrecu. U Novom Sadu primenjuje se od 2005. godine. Grad je podeljen na parkirne zone, one su:

- crvena,

- plava,

- bela.

\section{KARAKTERISTIKE PARKIRANJA NA DATOJ LOKACIJI}

Parkirališta koja su obuhvaćena u ovom istraživanju se nalaze na lokacijama:

- Trgu Republike,

- Daničićeve ulice,

- Lončarske ulice,

- ulice Aleksandra Tišme,

- Kosovske ulice

- $\quad \breve{S}$ umadijske ulice

$\mathrm{Na}$ nekim parkiralištima postoji sistem naplate, a na nekima ne. Snimanjem ulaska i izlaska vozila zapisivani su registarski brojevi, vreme ulaska i izlaska, posedovanje neke od pretplatničkih kartica ilio parking karti iz kioska. Ukoliko nije vidno uočljiva neka parking karta, predpostavlja se da je korisnik parking platio preko SMS poruke.

Snimanja su izvršena u dva dana, jedan radni (četvrtak) u periodu od $7 \mathrm{~h}$ do $21 \mathrm{~h}$ i jedan neradni dan (nedelja) u dva intervala od $8 \mathrm{~h}$ do $10 \mathrm{~h}$ i od $18 \mathrm{~h}$ do $20 \mathrm{~h}$, jer nedeljom najviše promena na parkiralištima ima u tim terminima. 


\subsection{Parkiralište na Trgu Republike}

Parkiralište na Trgu Republike kod Riblje pijace spada u zatvorena parkirališta koje je grad Novi Sad ustupio preduzeću "Parking servis" na korišćenje.

Nalazi se na lokaciji nekadašnje prigradske autobuske stanice koja je 2006. godine izmeštena iz centralne gradske zone. Ovo parkiralište se nalazi u crvenoj zoni, što znači da je zadržavanje do 120 minuta i parkiranje na ovom parkiralištu se obavlja pod uglom od $90^{\circ}$. Na parkiralištu ima 58 parking mesta, od toga su 2 za osobe sa posebnim potrebama.

- Parkiralište je koristilo na radni dan 1607 vozila, a na neradni 205 vozila (pre podne) $\mathrm{i}$ 167 vozila (posle podne)

- Najveći broj dolazaka i odlazaka zabeležen je u poslepodnevnim časovima

- Prosečna iskorišćenost parkirališta bila je $117 \%$ na radni dan, i na neradni dan $102 \%$ (pre podne) i $95 \%$ (posle podne).

- Zadržavanje do jednog časa čini skoro $87 \%$ korisnika na radni dan, a na neradni $76 \%$ (pre podne) i $79 \%$ (posle podne)

- Način plaćanja parkinga - preko $94 \%$ je platilo preko SMS poruke na radni dan, na neradni dan nema naplate za parking.

- Prosečan obrt je nepunih 27,71 vozila/par.mestu za radni dan, a za neradni 3,53 vozila/park.mestu za pre podne i 2,88 vozila/park.mestu za posle podne.

\subsection{Parkiralište u Daničićevoj ulici}

Parkiralište spada u ulična parkirališta, nalazi se između Kosovske ulice i Lončarske ulice. Na ovom parkiralištu postoji sistem naplate (plava zona). Parkiralište je obeleženo i broji 8 parking mesta od kojih je jedno za osobe sa posebnim potrebama. Parkiranje se vrši pod uglom od $60^{\circ}$.

- Parkiralište je koristilo na radni dan 32 vozila, a na neradni 7 vozila (pre podne) i 14 vozila (posle podne).

- Prosečna iskorišćenost parkirališta na radni dan je oko $84 \%$, a na neradni dan je $39 \%$ (pre podne) i $100 \%$ (posle podne).

- Na ovom parkingu na radni dan su izražena višećasovna zadržavanja, a na neradni dan su zadržavanja do jednog ćasa.

- Najpopularniji način plaćanja parking karte je slanjem SMS poruke, oko $56 \%$.

- Obrt parkiralištaje na radni dan je 4 voz/park.mestu, a na neradni dan je 0.88 voz/park.mestu (pre podne) i 1,75 voz./park.mestu (posle podne)

\subsection{Parkiralište u Lončarskoj ulici}

Ovo parkiralište se nalazi duž Lončarske ulice. Ona se nalazi između Daničićeve ulice i ulice Aleksandra Tišme, a paralelna je sa Kosovskom ulicom. Parkiralište broji 21 parking mesto, raspoređeno sa obe strane ulice.
- Parkiralište je na radni dan koristilo 86 vozila, a na neradni dan 22 vozila (pre podne) i 21 vozilo (posle podne).

- Na ovom parkiralištu slabe su izmene dolazaka i odlazaka.

- Prosečna iskorišćenost parkirališta na radni dan je preko $102 \%$, dok je na neradni dan bila $87 \%$ (pre podne) i $90 \%$ (posle podne).

- Zadržavanja do jednog časa čine oko $48 \%$ na radni dan, a na neradni dan dominiraju zadržavanja preko dva časa.

- Obrt parkirališta na radni dan je 4.1 voz./park.mestu, a na neradni dan oko1,9 voz./park.mestu.

\subsection{Parkiralište u ulici Aleksandra Tišme}

Ulica Aleksandra Tišme se nalazi paralelno sa Daničićevom ulicom i seče je Kosovska ulica. Na posmatranom parkiralištu ima15 parking mesta, od kojih je jedno za osobe sa posebnim potrebama. Parkiranje se izvodi pod uglom od $0^{\circ}$.

- Broj vozila koja su koristila parkiralište na radni dan je 74, a na neradni dan je po 17 vozila koristilo parkiralište pre i posle podne.

- Mali broj dolazaka i odlazaka po vremenskim intervalima, a na neradni dan je skoro pa statično.

- Prosečna iskorišćenost parkirališta na radni dan je oko $103 \%$, a na neradni dan je $110 \%$ (pre podne) i $83 \%$ (posle podne).

- Najviše ima zadržavanja do jednog časa, oko $45 \%$ na radni dan. Na neradni dan dominiraju zadržavanja preko dva časa, pre podne $88 \%$ i posle podne oko $65 \%$.

- Obrt parkirališta na radni dan je 4,93 voz./park.mestu, a na neradni dan je 1,13 voz./park.mestu.

\subsection{Parkiralište u Kosovskoj ulici}

Parkiralište koje ćemo posmatrati u Kosovskoj ulici se nalazi na delu ulice od Trga Republike do raskrsnice Kosovske ulice i ulice Aleksandra Tišme. Parkiralište je uličnog tipa, sadrži 35 parking mesta. Od kojih je 24 parking mesta pod uglom od $90^{\circ}$ sa leve strane ulice $(\mathrm{kad}$ se ide od Trga Republike prema ulici Aleksandra Tišme) i 11 parking mesta pod $0^{\circ}$ sa desne strane.

- Ukupan broj vozila koji je koristio parkiralište na radni dan je 138, a na neradni je po 63 vozila pre podne i posle podne.

- Najviše izmena je u periodu od $14 \mathrm{~h}$ do $16 \mathrm{~h}$, za radni dan. Na neradni dan je dosta aktivnije nego na radni u istim vremenskim intervalima.

- Prosečna iskorišćenost parkirališta je $84 \%$ za radni dan, a na neradni dan je $81 \%$ pre podne i preko $104 \%$ posle podne.

- Na radni dan zastupljenija su zadržavanja do jednog časa, među njima je najviše zadržavanja do 15 minuta. Na neradni dan u prepodnevnim satima dominiraju zadržavanja do 15 minuta, a 
posle podne je skoro odnos 50-50 zadržavanja do jednog sata i preko jednog sata.

- Obrt na radni dan je skoro 4 voz./park.mestu, a na neradni dan je 1,8 voz./park.mestu.

\subsection{Parkiralište u Šumadijskoj ulici}

Šumadijska ulica se nalazi paralelno u odnosu na Kosovsku ulicu, a upravna je na ulicu Trga Republike i Aleksandra Tišme Parkiralište koje ćemo posmatrati u Šumaddijskoj ulici je deo parkirališta od raskrsnice sa ulicom Trga Republike do raskrsnice sa ulicom Aleksandra Tišme. Parkiralište je uličnog tipa, parkiranje se vrši pod $0^{\circ}$ sa desne strane (kad se ide od Trga Republike) i pod uglom sa leve strane. Za procenu se uzelo da ima 19 parking mesta. Ovde je veliki broj parkiranih vozila na zelenoj površini.

- Ukupan broj vozila na radni dan je bio 62 , a na neradni dan po 45 vozila pre podne i posle podne.

- Zabeležene najveće vrednosti iskorišćenja parkirališta i najveća prosečna iskorišćenost, preko 221\%. Razlog je veliki broj nepropisno parkiranih vozila na zelenoj površini.

- $\mathrm{Na}$ ovom parkiralištu dominiraju višečasovna zadržavanja.

- Obrt parkirališta po formuli je 3,26 voz./park.mestu na radni dan, a na neradni dan je 2,37 voz./park.mestu. Realno stanje je da je obrt oko 1-1,5 voz./park.mestu.

\section{ANKETA}

Anketa je tehnika prikupljanja podataka i obaveštenja koji se primenjuju u društvenim naukama. Sprovodi se tako što veći broj ispitanika (koji čini uzorak) odgovara na pitanja $u$ vezi sa nekim određenim problemom ili pojavom. Anketni list sa preciznim pitanjima se dostavlja ispitanicima koji odgovaraju na pitanja iz raznih oblasti. Rezultati ankete se analiziraju i na osnovu njih se izvlače zaključci. Anketa u naučne svrhe znači skup izjava, stavova, mišljenja više učesnika kompetentnih da pruže odgovore na konkretno postavljeno pitanje.

Anketa se sprovodila oba dana kada je rađeno i brojanje i posmatranje parkirališta. Anketni list sadrži 13 pitanja i 3 pod pitanja, za neke odgovore su ponuđeni odgovori, a na neka su ispitanici samo unosili svoje odgovore.

- Najviše ispitanika je anketirano na parkiralištu na Trgu Republike.

- Odnos muških i ženskih ispitanika je bio 3:1.

- Preko 79\% ispitanika vozačku dozvolu poseduje više od 10 godina.

- Razlog dolaska na posmatrana parkirališta je najviše zbog posla.

- Najprihvatljivija cena mesečne karte za parkiranje je od 1000,00-1200,00 dinara, a godišnje od 7000,00-10000,00 dinara.

- Uglavnom su bili ispitanici koji svakodnevno dolaze na posmatrane parkinge.

- Najčešće je vozač bio sam u vozilu.
- Više se ispitanika izjasnilo kao nezadovoljni parkiralištem na Trgu Republike.

- Oko 2/3 ispitanika plaća parking uslugu na bilo koji način. Najčešće je to preko SMS poruke.

- Najprihvatljivije vreme pešaćenja je od 5 do 10 minuta od mesta parkiranja do cilja putovanja. Ili od 100-350m pešačenja.

- Kod načina snalaženja za parking većina kruži dok ne nađe slobodno parking mesto.

- Ispitanicima je najvažnija stvar kod parkirališta da ima dovoljno mesta.

- Najćešće kritike su da ima malo mesta, a najčešći predlog je podzemna garaža.

\section{UPOREDNA ANALIZA KARAKTERISTIKA PARKIRANJA NA POSMATRANOM PARKIRALIŠTU NA TRGU REPUBLIKE SA RANIJIM ISTRAŽIVANJIMA}

Prethodnih godina su rađena istraživanja na ovoj lokaciji radi stvaranja baze podataka za projekat izgradnje podzemne garaže. Pošto su prethodna istraživanja rađena na radni dan, iskoristićemo podatke iz našeg posmatranja na radni dan.

- Prosečna iskorišćenost 2009. godine je bila skoro $75 \%, 2011$. godine prosečna iskorišćenost je $69 \%$ i 2018 . godine je $119 \%$.

- Obim parkiranja se povećao za više od 2 puta 2018. godine , nego 2011. godine.

- $\quad 58 \%$ korisnika se zadržavalo do jednog časa na parkiralištu 2011. godine, $61 \%$ po istraživanjima iz 2018. godine i $87 \%$ po ovom istraživanju

- Plaćanje parking karte pomoću poruke se povećao naspram 2011. godine, razlog razvoj telkomunikacije i tehnologije.

- Obrt parkirališta 2011. godine je bio 6,48 voz./park.mestu, a 2018. godine 27,71 voz./park.mestu.

\section{PREDLOG MERA ZA REŠAVANJE PROBLEMA PARKIRANJA U POSMATRANOM DELU GRADA}

Predlozi mera koje bi mogle da doprinesu rešavanju problema parkiranja:

- Uvođenje sistema naplate, u ulice u kojima još ne postoji

- Postavljanjem rampe na parkiralište na Trgu Republike

- Prepravljanjem autobuskog stajališta kod Trga Republike u taksi stajalište

- Iscrtavanje parking mesta u jednosmernim ulicama

- Češće kontrole nadležnih organa

- Izgradnja graže u više nivoa.

Realizacijom navedenih mera smanjio bi se broj nepropisno parkiranih vozila, stvaranje zastoja i otežanog prolaska vozila, stvorili bi se uslovi da neke ulice postanu dvosmerne. 


\section{ZAKLJUČAK}

U ovom radu određene su karakteristike parkiranja na parkiralištima lociranim:

- na Trgu Republike,

- u Daničićevoj ulici,

- u Lončarskoj ulici,

- u Kosovskoj ulici,

- u ulici Aleksandra Tišme i

- u Šumadijskoj ulici.

Za potrebe izrade rada sprovedena su istraživanja koja su obuhvatila brojanje vozila koja u toku perioda istraživanja uđu, odnosno napuste parkiralište, pri čemu se beležio način palćanja usluge parkirališta (gde postoji sistem naplate) za ista vozila.

- Najveći obim i obrt na parkiralištu zabeležen je na parkiralištu na Trgu Republike

- Preko 94\% korisnika je parking kartu platilo SMS porukom

- Najmanja iskorišćenost parkirališta je zabeležena na parkiralištu u Daničićevoj ulici

- Najveća iskorišćenost parkirališta i najveća prosečna iskorišćenost parkirališta zabelezena je na parkiralištu u Šumadijskoj ulici. Veliki broj nepropisno parkiranih vozila.

Primećen je skoro 2,5 puta veći broj korisnika na parkiralištu na Trgu Republike 2018. godine nego po istraživanju iz 2011. godine.

Po svemu prikazanom, zabeleženom i primećenom dolazimo do zaključka da je na ovoj lokaciji potreba za parking mestom veća nego što parkirališta mogu da pruže. Možda jedno od boljih rešenje za rešavanje problema parkiranja na posmatranoj lokaciji, a i tog dela grada jeste pravljenje garaže (jedne ili više njih) u više nivoa.

\section{LITERATURA}

[1] Prof. Dr. Nikola Putnik: Autobaze i autostanice, Saobraćajni fakultet, Beograd, 1992.

[2] www.parkingns.rs/onama.php, (pristupljeno u avgustu 2018.)

[3] www.parkingns.rs/parkirališta.php, (pristupljeno u avgustu 2018.)

[4] Smart plan - prikupljanje podataka "Prva faza", Univerzitet u Novom Sadu, FTN, Departman za saobraćaj, 2017.

[5] Smart plan - "Druga faza", Univerzitet u Novom Sadu, FTN, Departman za saobraćaj, 2019.

[6] Dušan Marković, Diplomski rad, Novi Sad, 2012.

[7] www.google.com/maps/@ 45.2584603,19.8492572,19z, (pristupljeno u oktobru 2018.)

\section{Kratka biografija:}

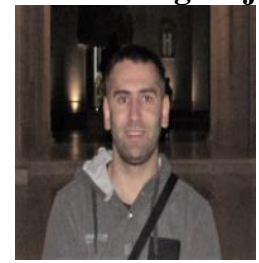

Perica Baić rođen je u Somboru 1985. god. Master rad na Fakultetu tehničkih nauka iz oblasti Saobraćaj - Drumski i gradski terminali odbranio je 30.10 . 2019.god.

Kontakt: pericabaic@gmail.com 